\title{
„Temporalizacja” Boga. \\ O czym mówią peryfrazy „roku Pańskiego” na stronach tytułowych starych druków
}

\author{
The "Temporalization" of God. What Do the Paraphrases of "Anno Domini" \\ on the Title Pages of Old Prints Speak of?
}

\author{
KATARZYNA JANUS \\ Uniwersytet Humanistyczno-Przyrodniczy im. Jana Długosza w Częstochowie \\ katarzynajanusx@wp.pl, ORCID: 0000-0003-4897-3621
}

\begin{abstract}
Streszczenie: W artykule zostały zaprezentowane i zinterpretowane peryfrazy wyrażenia „Anno Domini" umieszczone na stronach tytułowych XVII- i XVIII-wiecznych druków indeksowanych w Bibliografii Staropolskiej Karola Estreichera. Do interpretacji zostały wybrane zarówno peryfrazy odznaczające się walorami literackimi, jak i interesujące z uwagi na konteksty, aluzje, konotacje. Wśród prezentowanych wyrażeń znalazły się także chronogramy. Podjętą w szkicu naukową refleksję na temat tego fenomenu wydawniczego można potraktować jako prolegomena do kolejnych badań, ponieważ temat wydaje się wart zainteresowania. Krytyczne spojrzenie z perspektywy teologicznej, literaturoznawczej, lingwistycznej na nieopracowany dotychczas materiał może przyczynić się do poszerzenia wiedzy na temat kultury religijnej dawnych Polaków.
\end{abstract}

Stowa kluczowe: peryfraza, chronogram, Anno Domini, czas, stary druk

Abstract: In this paper examples of periphrasis of the words "Anno Domini" are presented. The phrases were selected from the title pages of old prints that were published in the 16th and 17th centuries and indexed in Bibliografia Staropolska of Karol Estreicher. The expressions analyzed in the article are particularly distinguished by the inventiveness of their authors and considered especially interesting due to their aesthetics and contexts. A part of this article is devoted to an analysis of chronograms. The scientific reflection referenced in this paper can be treated as prolegomena to further researches, since this phenomenon has thus far been the subject of little study and thus needs to be further analyzed from the theological, literary and linguistic perspectives. Philological considerations presented in the article are based on intertextual references and reflect the biblical, patristic and sensu largo cultural contexts.

Keywords: Periphrasis, Chronogram, Anno Domini, Time, Old Print

Bogusław Nadolski w następujący sposób opisuje czas Jezusa, wyróżniając ów czas jako jedną z jego - czasu - form:

Przyjściem Jezusa „wypełnił się czas”. Wieczność wkroczyła w czas. Ojcowie Kościoła używają na określenie „Wcielenia” słowa inchronizacja = wejście w czas. Dzieło Chrystusa było „temporalizacją" Boga. Nic dziwnego, że od tego momentu liczy się czas: Rozpoczynamy 
od szczytu - wcielenie Chrystusa, czas przed narodzeniem Chrystusa i po narodzeniu kontynuacja czasu wypełnionego Bogiem aż do powtórnego przyjścia ${ }^{1}$.

Mianem sui generis fenomenu wydawniczego możemy nazwać pojawiające się na stronach tytułowych starych druków peryfrazy tego szczytowego punktu w czasie, od którego liczy się nasza era. Zwłaszcza jeśli spojrzymy na ów fenomen ze współczesnej perspektywy początków XXI wieku. Czas liczony od przyjścia Chrystusa w żaden sposób nie jest już dziś odnoszony w sposobie datacji do tej oczywistości. Ablativus temporis „anno Domini”, element archaicznej stylizacji, pojawiający się zazwyczaj w formie pisemnej w celu podkreślenia wagi jakiegoś wydarzenia, funkcjonuje jako formuła coraz rzadziej. Celem niniejszego szkicu jest poszerzenie wiedzy na temat horyzontu językowego dawnych Polaków, ich czytelniczych gustów, naprzeciw których wychodzili bibliopole, sposobu wyrażania przywiązania do systemu wartości. Wybrane do analizy i interpretacji przykłady pochodzą z dostępnej w wersji cyfrowej bazy Bibliografii Staropolskiej Karola Estreichera (https://www.estreicher.uj.edu.pl/ staropolska/). Bibliografia polska ${ }^{2}$ była w opinii współczesnych Estreicherowi badaczy źródłem danych wzbogacających wiedzę nie tylko o piśmiennictwie epok dawnych, ale także o obyczajach, religijności, kulturze literackiej, czytelnictwie. W publikacji z 1945 roku możemy przeczytać słowa historyka literatury Wiktora Weintrauba o Bibliografii:

Jest ona jakby mapą dla podróżnika odkrywcy, nakreślającą granice dziewiczego terenu, drogi podejścia, sugerującą, gdzie prawdopodobnie będzie można zrobić najciekawsze odkrycie. Nie ma prawie arkusza Bibliografii, który by nie podsuwał interesujących problemów do opracowania, nie wskazywał na tematy leżące odłogiem a obiecujące ciekawe wyniki³.

Dzięki dokładności opisów książek w bibliografii Karola Estreichera możemy znaleźć liczne peryfrazy określeń początku chrześcijańskiej ery, będące wyrazem twórczej inwencji ich autorów ${ }^{4}$, odwołujących się do religijnej świadomości, znajomości Biblii oraz do teologicznej wiedzy odbiorców. Podjęta w niniejszym studium kwestia eksplikacji peryfraz „anno Domini” - danej bibliograficznej ze stron tytułowych druków dawnych - nie doczekała się, jak dotąd, naukowej refleksji, a z pewnością na to zasługuje. Elektroniczna Baza Bibliografii Estreicherów (EBBE) ${ }^{5}$ stanowi

\footnotetext{
Nadolski, Liturgika, 9.

Estreicher, Bibliografia polska, I-XXII.

Weintraub, „Ostatni tom Bibliografii Estreichera”, 243.

Byli to najpewniej wydawcy. Jeśli pojawia się w Bibliografii kilka edycji, opisy na stronie tytułowej są różne. Projekt realizowany nieustannie od 2012 r. przez zespół profesora Wacława Waleckiego. Zob. na ten temat: Nastulczyk, „Elektroniczna Baza Bibliografii Estreichera”, passim; Kowalewska, „System Elektronicznej Bazy Bibliografii Estreichera", 386-395.
} 
udogodnienie w zakresie możliwości korzystania z bibliografii. Użytkownicy mają dostęp zarówno do skanów książkowych stronic, jak i opisów według kryterium poszczególnych danych. Można zatem, jak to ma miejsce w niniejszym studium, potraktować cyfrową wersję bibliografii jako korpus w znaczeniu, w którym termin funkcjonuje w językoznawstwie.

We współczesnej lingwistyce korpusowej - czytamy w opracowaniu leksykograficznym o możliwości nazwania zbioru tekstów korpusem decyduje stopień ich uporządkowania i możliwość automatycznego przeszukiwania ${ }^{6}$.

Łacińskie słowa „anno Domini”, w dosłownym tłumaczeniu „roku Pana”, oznaczające punkt na linii czasu, od którego liczy się era chrześcijańska, zostały wprowadzone w 525 roku na prośbę papieża Jana I przez Dionizego Małego, rzymskiego kanonistę i chronografa. Sposób użycia rozpowszechnił Beda Czcigodny. Od X wieku datowanie chrześcijańskiej ery poprzedzone słowami „anno Domini” było powszechne w całej Europie ${ }^{7}$. W Polsce chrześcijańską rachubę - erę dionizyjską - wprowadzono wraz z przyjęciem chrztu. Na określenie lat stosowano - poza najczęstszą formą „anno Domini” - także inne, często peryfrastyczne, jak np. anno reparatae salutis, anno Dominicae incarnationis, anno verbi incarnati, anno orbis redempti ${ }^{8}$.

Wybrane według kryterium inwencji oraz elokucji - jeśli użyć terminów retorycznych - peryfrazy czasu, a właściwie punktu w czasie, od którego liczone są kolejne lata - dane pojawiające się w opisie bibliograficznym, stanowią interesujące znaki tamtych czasów.

Peryfraza jest definiowana jako „wielowyrazowe określenie osoby, rzeczy, miejsca lub pojęcia, używane zwykle ze względów ornamentacyjnych lub eufemizacyjnych,

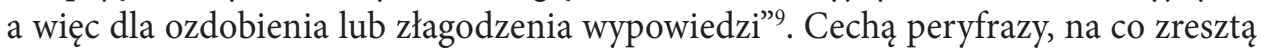
wskazuje źródłosłów, jest wyrażanie omowne. Peryfrazę, jako środek obrazowania poetyckiego, stanowi „wyrażenie złożone o charakterze opisowym lub przenośnym, nazywające nie wprost i zastępujące nazwę właściwą" ${ }^{\prime 1}$. Z samej swej natury peryfraza należy do stylu bogatego. Powoduje aktywność poznawczą odbiorcy. Będąc domeną interpretacji, narzuca określoną wizję opisywanego zjawiska ${ }^{11}$. Określenia wskazane jako początek „naszej ery” są tożsame, jeśli chodzi o ich funkcję informacyjną, oznaczają bowiem czas Bożego Narodzenia. Jednak dzięki środkom obrazowania

6 Majdak, Głos, 32. W formułowanych w ostatnich latach w związku ze wzrostem znaczenia i dostępności cyfrowych wersji tekstów naukowych, definicje „korpusu” poddawane są szczegółowym opisom. Zob. ibidem, 24-35.

7 Drączkowski, „Dionizy Mały”, 1340-1341; Szlaga, „Anno Domini”, 631-632.

8 Wąsowicz, „Era chrześcijańska”, 1060.

9 Machnicka, „Konstrukcje peryfrastyczne”, 5.

10 Bańko, „Peryfrazy w naszym życiu”, 5.

11 Głowiński, „Peryfrazy współczesne”, 49. 
przestają być przezroczyste i wywołują liczne skojarzenia; odsyłają czytelnika również do zdarzeń, zjawisk, tekstów kultury wymagających dodatkowej eksplikacji. Co w kontekście niniejszych rozważań jest szczególnie istotne, stanowią wspomnienie i uobecnienie wydarzeń zbawczych, czyli anamnezę ${ }^{12}$. Choć określają cezurę czasu naznaczoną narodzeniem Chrystusa, często nawiązują także do zwiastowania czy ukrzyżowania. Powstaje zatem świadectwo, jakie w ten sposób dawano objawieniu. Widniejące na stronach tytułowych dogmaty - magnalia Dei, które według nauki Kościoła „powinny być interpretowane w całości Starego i Nowego Testamentu według analogii wiary”'13, „domagają się” takiej właśnie interpretacji.

Strony tytułowe edycji barokowych - ukazujących się w XVII wieku i pierwszej połowie XVIII stulecia - a na nich bibliograficzne dane roku wydania, okazują się najbardziej interesujące. W tym bowiem czasie żarliwość religijna kształtowała zbiorową świadomość. Ekspresji religijnej podporządkowany był koncept i ozdobny styl, charakteryzujący się kunsztownymi peryfrastycznymi wyrażeniami. Pełniły one funkcję propagandową. Na temat tej właśnie funkcji trafnie wypowiada się Michał Głowiński. Sformułowane odnośnie do formuł propagandowych XX wieku słowa można odnieść także do wyrażeń przywołanych w niniejszym studium.

Atrakcyjność peryfrazy [...] polega na tym, że interpretując, dokonuje identyfikacji przedmiotu z wybranymi cechami, uznanymi za najistotniejsze czy po prostu jedynie ważne. Peryfraza ma być obowiązującą kwalifikacją przedmiotu, językową etykietą na stałe z nim związaną. Istnieje swoista niepisana umowa pomiędzy autorami, używającymi takich formuł, a czytającą publicznością, umowa, która każe je traktować jako konstrukcje w pełni konwencjonalne i w jakimś sensie - zastępcze ${ }^{14}$.

W dwudziestu dwóch tomach Bibliografii polskiej Karola Estreichera możemy znaleźć bardzo wiele peryfraz „roku zerowego”, którego najprostsze omówienie, wskazujące na Boga jako władcę czasu - „anno Domini” - funkcjonuje w powszechnej językowej świadomości. Ablativus temporis „anno” jest tu czymś oczywistym i stałym. To, co zmienne, co w sposób opisowy określa ów rok, odnosi się do niego dzięki użyciu przydawki dzierżawczej wyrażonej genetiwem. W niektórych wypadkach całe wyrażenie możemy sprowadzić do rzeczownika w nominatiwie i zadać pytanie: kim jest Chrystus? Odpowiedzieć: vita nostra - naszym życiem, salus humana - ludzkim wybawieniem czy princeps pacis - księciem pokoju. Jednak są to wyrażenia stojące w dopełniaczu, informujące o tym, do kogo ów rok (annus) należy. Warto też zasygnalizować różnicę w strukturze omówień: w części został użyty przyimek $a b$ (w peryfrazach w języku polskim - od), na wzór wyrażenia „ab Urbe con-

\footnotetext{
Kowalczyk, „Anamneza”, 511.

Sobór Watykański II, „Konstytucja Dei verbum”, 12.

Głowiński, „Peryfrazy współczesne”, 50.
} 
dita”. Ab wskazuje ów moment na linii czasu, od którego liczy się nowa era. W wielu określeniach czasu zasygnalizowana wyrazem „od” $(a b)$ cezura na poziomie leksyki nie pojawia się. Przyjęta konwencja zwalnia czytelnika z logicznych dociekań. Nawet jeśli peryfraza odnosi się do wydarzeń, które stały się udziałem dorosłego Chrystusa, takich jak chrzest, ukrzyżowanie, wniebowstąpienie, to i tak wiadomo, że czas jest liczony od Narodzenia.

Wybrane do prezentacji przykłady są jedynie niewielką egzemplifikacją konstrukcji opisowych bibliograficznej danej roku wydania. Za kryterium wyboru przyjęto przede wszystkim kognitywną funkcję przykładów, w której realizacji ujawniają się możliwości języka jako narzędzia interpretowania świata. Z uwagi na różnorodność prezentowanych wyrażeń, trudno dokonać ich klasyfikacji. We wszystkich zauważamy walory literackie. Różny jest stopień skomplikowania omówień. Można wyróżnić takie, których zrozumienie nie wymaga kontekstowych poszukiwań. Autorzy odwołują się w nich do znanych katolikom prawd wiary. I choć te ostatnie zasadzają się na paradoksie, możemy tu powiedzieć o quasi-realizmie, by odróżnić konstrukcje omowne niewymagające wskazania inwencyjnych źródeł; jasne, od takich, w których dogmaty stanowią fundament, na którym zbudowano wypowiedzi o charakterze przenośnym z szerszą płaszczyzną odniesień i konotacji, wymagające komentarza. Jeszcze inną grupę wykorzystanych w niniejszym studium peryfraz „anno Domini” stanowią chronogramy, wśród których są zarówno proste omówienia, jak i prawdziwe zagadki, co wynika już z samej formy graficznej. W większości przykładów zauważamy leksykalny związek pomiędzy tytułami utworów a wyrażeniami omownymi roku edycji. Zaskakujące są peryfrazy towarzyszące tytułom utworów, najczęściej panegiryków, autorów XVII i XVIII wieku. Jest to związane zarówno z liczbą druków, jak i literackim gustem. Okazuje się, że koncept, antyteza, metafora - cechy stylu barokowego - pojawiają się w obfitości już na stronach tytułowych utworów. O peryfrazie XVIII-wiecznej napisze znawczyni tematu, że „oprócz pełnienia funkcji zdobniczej, wymagała od czytelnika właściwego jej rozszyfrowania, warunkującego zrozumienie utworu"15. Tę opinię można odnieść także do wcześniejszych peryfraz, będących - obok oświeceniowych - przedmiotem eksplikacji w niniejszym studium; z zastrzeżeniem, że nie chodzi tu o zrozumienie treści tekstu zapowiedzianego na stronie tytułowej, ale o zrozumienie mentalności ludzi, specyfiki działalności oficyn, roli bibliopolów, słowem - o przeniknięcie w tamten czas.

Anno Vinculati Cum Natura Humana Verbi Incarnati [W roku wcielonego Słowa związanego z ludzką naturą]. Ter gemini vinculi... (Żeliński, 1719) ${ }^{16}$ zaczyna się tytuł laudacji trzech dekanatów archidiakonatu pszczewskiego. Słowo „więzy” (vinculi)

15 Machnicka, „Konstrukcje peryfrastyczne”, 344.

16 Wszystkie przykłady, w celu zlokalizowania ich w cyfrowej bazie Bibliografii Staropolskiej, będą opatrzone pierwszym wyrazem hasła i rokiem wydania w nawiasie okrągłym. Przekład własny w nawiasie kwadratowym. Ortografia według zapisu w bazie; https://www.estreicher.uj.edu.pl/staropolska/baza/ [dostęp: 28-10-2020]. 
wydało się twórcom atrakcyjne do wykorzystania w omówieniu „roku Pana” ze względu na odniesienie do tytułu. Choć już samo wyrażenie „wcielone Słowo” wskazuje na Jego związanie z ludzką naturą, to nie wyczuwamy w peryfrazie tautologii. Wymiar estetyczny ma układ wyrazów. Zauważamy foniczną organizację. Symetrycznie, wokół słów Cum Natura Humana układają się wyrazy: Anno Vinculati i Verbi Incarnati.

Roku którego się Kwiat Niebieski na ziemi w śmiertelna naturę rozwiną (Staniewski, 1719). Tak opisany został rok wydania panegiryku pogrzebowego, którego tytuł zaczyna słowo Róża, a ta, jak czytamy dalej w tytule, „szczęśliwą na Niebie transplantacyą w koronę wieczności rozkwitła" ${ }^{17}$. Barokowy koncept nie jest tu pozbawiony walorów literackich: kwiat, który rozwija się w śmiertelną naturę to udana metafora Chrystusa, uwzględniająca paradoks Bożego Narodzenia. Antytetyczne jest zestawienie rozwijającego się kwiatu ze śmiercią. Warto też zaznaczyć, że bardzo rzadkie są XVII- i XVIII-wieczne edycje, w których peryfrazy roku wydania zapisane są na stronach tytułowych po polsku. Z tej ostatniej konstrukcji omownej jasno wynika, że nie chodzi o wskazanie czasu, który upłynął od Bożego Narodzenia. Opis odnosi się do roku bieżącego, jak w przeważającej części edycji. Wydawcy wskazują kairoi wydarzenia w historii zbawienia, przywoływaniem których w pewnym sensie dokonują anamnezy - w sposób mistyczny te wydarzenia unaoczniają. Można powtórzyć za Bogusławem Nadolskim, definiującym czas biblijny, że także w wyrażeniach omownych odnoszących się do roku zerowego „Bóg czyni sam siebie współczesnym człowiekowi”18.

Róża, która pojawiła się w tytule utworu, często występuje także w peryfrazach „anno Domini”, np. Anno quo Rosa sine spinis Florem in fructum vitae Coelestis enixa est [Roku, którego róża bez kolców kwiat wydała na owoc życia niebieskiego 1712] (Pruski, 1712). Tym razem róża pojawia się w tytule i opisie roku wydania mowy pogrzebowej. Róża bez kolców od pierwszych wieków chrześcijaństwa symbolizuje Matkę Bożą. Najstarszym świadectwem tej symboliki są wersety Poematu paschalnego Seduliusza: „Jak wśród ostrych cierni wyrasta róża/ Miła niczego nie mając, co szkodzi i czcią matkę/ Osłania, tak z przyjściem Świętej Marii z korzenia Ewy/ Nowa Dziewica występek dawnej naprawić miała"19. Jako nowa Ewa występuje Maryja w kolejnej peryfrazie: Anno quo aeterno Patri Mater pulchrae dilectionis filios irae reconciliavit [W roku, w którym wiecznemu ojcu Matka pięknej miłości synów gniewu pojednała] (Albrychowicz, 1749). Tekst jest laudacją wizerunku Maryi z XVI-wiecznego obrazu w Tuchowie. W treści wyrażenia omownego roku wydania możemy odnaleźć aluzje, których odczytanie wskazuje na bogaty teologiczny sens tekstu. Pojawia się tutaj określenie Maryi „Mater pulchrae dilectionis”. W Biblii odnosi się ono

\footnotetext{
Tego typu metaforyka jest bardzo częsta w barokowych panegirykach.

Nadolski, Liturgika, 9.

Sedulius, „Paschale carmen”, 121.
} 
do mądrości, liturgia zaś przenosi je na Maryję. „Ego mater pulchrae dilectionis, et timoris, et agnitionis, et sanctae spei. In me gratia omnis viae et veritatis: in me omnis spes vitae et virtutis" (Syr 24,24-25). Wezwanie do Matki pięknej miłości pojawia się też w dawnej litanii loretańskiej, występującej w modlitewnikach kapucyńskich jako, litania de titulis B. V. Mariae ex Sacra Scriptura desumptis"20. Wezwane "Mater pulchrae dilectionis” jest drugim w litanijnym wyliczaniu. „Piękna miłośc” - cecha Maryi - jest akcentowana w kontekście Niepokalanego Poczęcia ze względu na Chrystusa. Dość przeczytać komentarz do określenia Mater pulchrae dilectionis w opublikowanej w 1730 roku laudacji o Niepokalanym Poczęciu: „Quomodo Virgo Sacratissima originalem culpam incurrere potuit, quae Mater est Pulchrae Dilectionis, id est Christi. Si ergo Maria Dilectio Christi est, non poterat non immaculate concepta esse, quia fuit Mater Dei" ${ }^{21}$. Aluzję do średniowiecznego toposu Maryi jako nowej Ewy odczytujemy w słowach "reconciliavit filios irae”. Fraza ma swoje źródło w Liście do Efezjan: „Et vos, cum essetis mortui delictis et peccatis vestris, in quibus aliquando ambulastis secundum saeculum mundi hujus, secundum principem potestatis aeris hujus, spiritus, qui nunc operatur in filios diffidentiae, in quibus et nos omnes aliquando conversati sumus in desideriis carnis nostrae, facientes voluntatem carnis et cogitationum, et eramus natura filii irae, sicut et ceteri” (Ef 2,1-3). Fragment ten doczekał się wielu komentarzy ${ }^{22}$. Warto tu przywołać egzegetyczną glosę Piotra Lombarda: „Et eramus, nos Iudaei, sicut et caeteri, id est gentiles, filii irae, id est debitores aeternae poenae, et hoc natura, id est per patres, Adam scilicet et Evam, id est per peccatum originale ab eis traductum"23. Dokładną sekwencję słów użytych w peryfrazie - „filios irae conciliavit” - znajdujemy w kazaniu na dzień Pięćdziesiątnicy Marcina z Leónu ${ }^{24}$. Sui generis proces pogodzenia, które ostatecznie nastąpiło za sprawą odkupienia, zapoczątkowała Maryja w Jej niepokalanym poczęciu, predestynującym Ją do Bożego Macierzyństwa. „Co Jewa smętna straciła, Tyś przez Syna naprawiła" - czytamy także w staropolskim przekładzie średniowiecznej sekwencji25. Biblijna Ewa jest pierwszą zapowiedzią, prefiguracją Maryi. Antyteza Ewa - Maryja eksponowana jest równie często w pismach Ojców Kościoła. „Mówi tedy Anioł do Maryi o Zbawieniu, jak niegdyś do Ewy o upadku" - głosi św. Piotr Chryzolog w homilii na Zwiastowanie Maryi ${ }^{26}$. Święty Albert Wielki w komentarzu do Ewangelii św. Mateusza $(1,18)$ cytuje fragment sekwencji Ave maris stella..., w której mowa o takiej dynamicznej zmianie/zamianie, skutkującej odkupieniem człowieka: „Funda nos in

\footnotetext{
Klawek, „Biblijne symbole maryjne”, 222.

Hipper, Maria Virgo Sacratissima.

Mehlmann, Natura filii irae, passim.

Petrus Lombardus, Collectaneorum in Epistolas Paulum (PL 192, 180D).

Martinus Legionensis, Sermo XXXII (PL 208, 1240D).

Quod Eva tristis abstulit,/ Tu reddis almo germine. Cyt. za: Hanusz, O książce do nabożeństwa, 28.

Piotr Chryzolog, „Homilia na Zwiastowanie Najświętszej Panny”, 131.
} 
pace,/ Mutans Hevae nomen [Utwierdź nas w pokoju,/ zmieniając Ewy imię]”. Poprzez tę przemianę nastąpiło pogodzenie: Maryja „filios irae reconciliavit”.

Maryjna symbolika pojawia się także w omówieniu roku wydania panegiryku wygłoszonego na cześć profesorów Akademii Krakowskiej. Adresaci zostali w tytule określeni mianem "grati odoris flores”. Peryfraza anno floris Nazaraei in Horto concluso vernantis [w roku Nazarejskiego kwiatu kwitnącego w zamkniętym ogrodzie] (Mamczyński, 1719) zawiera cytat wersetu z Pieśni nad Pieśniami: „hortus conclusus soror mea sponsa, hortus conclusus fons signatus" $(4,12)$. Słowa te symbolizują czystość Maryi i Jej niepokalane poczęcie. W średniowiecznych malarskich przedstawieniach otoczony murem ogród jest także miejscem przebywania Matki Bożej trzymającej na ręku Jezusa - niemowlę. Maryja siedzi w ogrodzie wśród kwiatów, najczęściej są to róże, które symbolizują Jej cnoty. Inną grupę przedstawień stanowią sceny Zwiastowania NMP, które ma miejsce również w „zamkniętym ogrodzie”27. Dobrze znaną aktualizacją malarską tego motywu jest fresk Zwiastowanie Fra Angelico w Museo di San Marco we Florencji. Związany z hortus conclusus motyw Zwiastowania NMP jako polowania na symbolizującego Chrystusa jednorożca, możemy zobaczyć w Polsce na fresku w kościele św. Jerzego w Ziębicach ${ }^{28}$.

Pozostając w kręgu maryjnych omówień, przywołajmy kolejne, tym razem o oczywistej biblijnej proweniencji: Anno, a quo virga de radice Jesse fructum vitae orbi reddidit ${ }^{29}$ [Roku, od którego różdżka z pnia Jessego owoc życia światu oddała] (Kuuk, 1719). Utwór jest panegirykiem na cześć Antoniego Aleksandra Fredry, krewnego komediopisarza, w dniu objęcia przez niego biskupstwa w Chełmie. Twórca peryfrazy nie zainspirował się tytułem. W opisie roku wydania pojawia się separatywne „a”, to znaczy, że autor zadbał, by wskazany rok był odczytany jako 1719 od narodzenia Chrystusa. Konsekwentnie też użyty został czasownik „reddidit”, w którym przedrostek „re-” wskazuje na powtarzanie, cykliczność czynności. Peryfraza czerpie z 11 rozdziału Księgi Izajasza ${ }^{30}$, który odnosi się do rodu Matki Jezusa opisanej jako „virga de radice Jesse”. Przepowiednia mesjańska: „et egredietur virga de radice Jesse et flos de radice eius ascendent", mówi o Chrystusie, pochodzącym z rodu Jessego, ojca Dawida. Odnosi się jednak też do Maryi jako wywodzącej się również z rodu Dawidowego ${ }^{31}$. Średniowieczni kaznodzieje, autorzy hymnów liturgicznych, wykorzystywali foniczną zbieżność wyrazów „virga” i „virgo”, dzięki czemu w wielu tekstach różdżka pojawia się w opisie dziewicy Maryi, np.: „Virga Iesse dedit florem/

\footnotetext{
27 Jacniacka, „Hortus conclusus”, 1238.

28 https://polska-org.pl/5612250,foto.html?idEntity=6343348 [dostęp: 28-10-2020].

29 W Bibliografii błędnie wydrukowano: roddidit.

30 „Et egredietur virga de radice Jesse, et flos de radice ejus ascendet. Et requiescet super eum spiritus Domini: spiritus sapientiae et intellectus, spiritus consilii et fortitudinis, spiritus scientiae et pietatis; et replebit eum spiritus timoris Domini" (Iz 11,1-3).

31 Klawek, „Biblijne symbole maryjne”, 220.
} 
Nostra virgo Salvatorem/ Sine viri semine”; „Virgo Santa virga est/ Flos de virga Christus est/ Splendens late"32.

W licznych hymnach i prozach średniowiecza możemy znaleźć te same symbole maryjne, które są obecne w prezentowanych w niniejszym studium peryfrazach, np. „Ave, conclusus hortulus, / In quo ortus est flosculus./ [...] Ave virgo eximia. [...] Ave virga miraculo/ florens in tabernaculo" 33 .

Niezależnie od stopnia zretoryzowania wyrażeń omownych bibliograficznej danej roku wydania, erudycji i pomysłowości ich autorów, ostatecznie chodzi w nich zawsze o wskazanie osoby Chrystusa. Przy pierwszej lekturze konotacje nie są oczywiste i należy podążać tropem aluzji, skojarzeń, by w końcu, dzięki zarysowanej płaszczyźnie intertekstualnej, odczytać intencje autora i zrozumieć przekaz.

Takim wyrażeniem, wymagającym rozszyfrowania, może być peryfraza: anno aquilae grandis, medullam cedri ad Libanum ferentis [w roku wielkiego orła przynoszącego gałązkę cedru do Libanu] (Augurium, 1681). To utwór, którego tytuł zaczynają słowa „Augurium paludatae sortis ex septena aquila septeni consulatus interprete Caio Mario Consuli [...]”, w filologicznym przekładzie brzmiące następująco: „Wyjaśniona Consulowi Gajuszowi Mariuszowi wróżba żołnierskiego losu siedmiokrotnego konsulatu z siedmiu części orła" ${ }^{34}$. Z kolejnych słów tytułu wynika, że druk to retoryczna, utrzymana w żartobliwym tonie, wprawka poświęcona koledze przez grupę młodych adeptów łowickiej szkoły pijarów. Orzeł z legendarnej biografii rzymskiego konsula spotyka się w bibliograficznej danej roku wydania z orłem - jak się okazuje po poszukiwaniach - z Księgi Ezechiela: „Aquila grandis magnarum alarum, longo membrorum ductu, plena plumis et varietate, venit ad Libanum et tulit medullam cedri” (17,3). Dla dzisiejszego czytelnika związek starotestamentowego orła z erą chrześcijańską nie jest jasny. Wiadomo jednak, że cytacja jest w tym miejscu nieprzypadkowa. Znając metody egzegezy biblijnej, zagadnienia prefiguracji, zasady alegorycznego wykładu natchnionych słów Pisma, możemy mieć nadzieję na odszukanie zaspokajającej ciekawość interpretacji użytego w publikacji biblijnego fragmentu. Z pomocą przychodzi homilia św. Antoniego Padewskiego ${ }^{35}$, rozpoczynająca się tym samym fragmentem Biblii. Jego egzegeza jest następująca:

Aquila, ab acumine visus sic dicta, Est beatus Ioannes, qui subtili mentis intuitu supra se elevatus Unigenitum Filium, qui est in sinu Patris, Verbum, quod erat in principio, vidit

32 Blume - Dreves, Analecta Hymnica medii aevi, XXXVII, 77 i XXXIX, 40.

33 Blume - Dreves, Analecta Hymnica medii aevi, XXXVIII, 177.

34 Według legendy Mariusz (157-86) jako młodzieniec znalazł gniazdo z siedmioma orlętami. Orły były czczone jako zwierzęta Jowisza. Zdarzenie uznano za omen zapowiadający siedmiokrotną elekcję Mariusza na stanowisko konsula. Zob. https://www.imperiumromanum.edu.pl/biografie/gajusz-mariusz/ [dostęp: 08.05.2020]. W tytule prawdopodobnie błędnie została użyta forma liczebnika septenus.

35 Kult świętego szerzył się w Polsce od połowy XVII wieku. Zob. Bilska-Wodecka et al., „Kult św. Antoniego w Polsce", 285. 
et nobis enarravit. [...] Ioannes in aquila, quae ceteris avibus altius volat, et ipse ceteris altius patefecit arcanum [Orzeł, który od ostrości widzenia jest nazwany, to błogosławiony Jan. Wyniesiony dzięki zdolności wnikliwego pojmowania ponad siebie zobaczył Jednorodzonego Syna, który jest w łonie Ojca, Słowo, które było na początku i nam opowiedział. Jest zatem Jan w postaci orła, który lata wyżej od innych ptaków, sam głębiej od innych wyjaśnia tajemnice $]^{36}$.

W licznych peryfrazach roku wydania pojawia się pochodna wyrazu „fascia”. To nazwa „nałęczki”, elementu herbu Nałęcz, insygnium wielu adresatów barokowych panegiryków, jak np. w tytule, który zaczynają słowa Culmus ad culmen fasciatus sacra inaugurationis die ad Culmensem mitram [...] [Bukiet związany przez wzgląd na urząd w świętym dniu wstępu na biskupstwo chełmińskie] (Małachowski, 1676). Zauważamy tu paronomazję. Pretekstem do jej zastosowania stała się nazwa własna Culmensis - chełmińska. Stąd i culmus - o znaczeniu kłos, źdźbło i culmen jako szczyt, ale także zaszczyt, urząd. Konstrukcja omowna roku wydania - anno Dei ad fasciculum Hominis fasciati 1676 jest trudna do przekładu. Fasciatus pojawia się obok fasciculus (deminutivum rzeczownika fascis), dając, dzięki paronomazji, efekt brzmieniowy. Występuje podobna gra słów jak w tytule. Forma fasciatus (imiesłów czasownika fasciare) odnosi się do Boga-Człowieka. W Wulgacie nie występuje ten wyraz, ale Chrystusa jako puer fasciatus, w znaczeniu owiniętego niemowlęcia, odnajdujemy w tekstach dawnych ${ }^{37}$. Fasciatus - „owinięty bandażami, opaskami” przywodzi na myśl wizerunek Jezusa z bożonarodzeniowych ikon, gdzie żłóbek jest zapowiedzią grobu, stąd grzebalne bandaże, które owijają niemowlę. Tłumaczenie wyrazu fasciculus sprawia trudność. Rzeczownik fasciculus sześciokrotnie występuje w Wulgacie ${ }^{38}$. Najpewniej rozwiązanie zagadki stanowi barokowa egzegeza fragmentu Księgi Pieśni nad Pieśniami $(1,12)$ zawarta w Kazaniach na niedziele całego roku Franciszka Rychłowskiego, wydanych w krakowskiej oficynie Stanisława Piotrowczyka w 1664 roku. Kaznodzieja wyjaśnia znaczenie obecnego w naszej peryfrazie leksemu fasciculus w następujący sposób:

Iż i trzecie ziołko w pasterniku naszym to jest Chrystus ile Odkupiciel jest owieczkom to jest duszom ludzkim dziwnie smaczne, dowodzę. Oblubienica o tym ziołku, Chrystusie Odkupicielu, tak spiewa Cant, I Cap. Fasciculus myrrhae dilectus meus mihi; inter ubera mea commorabitur. Snopeczek mirry ukochany mój mnie, między piersiami moimi mieszkać będzie". Patrzcie, snopek ciernia, biczów, powrozów, rózg, goździ, między piersiami dusze ludzkiej sprawiedliwej postawiony być ma. A czemuż to? Wzdyć od piersi słodkie wypływa mleko, czyli też także od tego snopeczka; tak zaiste. $\mathrm{Z}$ tego snopeczka to jest

\footnotetext{
Antonius Patavinus, In Festo S. Ioannis Evangelistae, 5-6.

Zob. np. Cornelius a Lapide, „Commentaria in librum sapientiae”, 871; Vivien, Tertullianus Praedicans, 64. $1 \mathrm{Krl}$ 25,29; Kpł 23,11; Iz 58,6; Am 9,6; Pnp 1,12; Mt 13,30.
} 
Chrystusa Odkupiciela, dla nas umęczonego, gdy go kto nabożnie i pilnie rozmyśla, płynie słodkie mleko, to jest smak wielki czuje ten, który rozmyśla mękę Jezusowę 39 .

Po polsku peryfraza brzmi dość niezbornie: „w roku Boga Człowieka w snopeczek związanego" ${ }^{40}$.

Stopień skomplikowania przy wyjaśnianiu peryfraz „anno Domini” zwiększa się w licznie reprezentowanych w drukach dawnych chronogramach. To takie wyrażenia, w których roczną datę daje zsumowanie liter-liczb rzymskich wyszczególnionych w wyrazach majuskułą. Te sui generis literackie zabawy powstawały według określonego schematu: litery o umownej liczbowej wartości, których suma stanowiła rok wydania, były konstantami. Należało tak dopisać pozostałe litery, by powstały wyrazy o określonym znaczeniu. Ta forma literacka najczęściej występowała w XVII i XVIII wieku ${ }^{41}$. W XIX stuleciu pisał o chronogramach ich kolekcjoner James Hilton ${ }^{42}$. W rozdziale poświęconym stronom tytułowym boleje on nad rzadkością chronogramów na tychże stronach wydań literatury angielskiej. Akcentuje za to ich obfitą reprezentację w drukach niemieckich i flamandzkich. Nie wspomina o polskich stronach, choć „chronogramiczny” akcent polski pojawia się w rozprawie w innym kontekście ${ }^{43}$. Hilton pisze o stronach tytułowych utworów:

The title-pages of books have, to a considerable extent, afforded opportunity for the application of chronograms, in order to set forth their date. It is probable, however, that the general reader is puzzled rather than informed, and he is apt to conclude that the title-page bears no date when it is expressed by chronograms instead of figures. ${ }^{44}$

Autorzy opracowań powstałych w języku polskim na temat chronogramów, a zwłaszcza chronostychów, czyli kompozycji wierszowych zawierających datę, zwracają uwagę na warsztat twórców, nie na znaczenie poszczególnych wyrażeń ${ }^{45}$. Jeśli chodzi o estetykę tych „rocznych” przekazów, warto wspomnieć o zasługach na tym polu Juliana Tuwima. Poeta w „panoptikum poetyckim” Pegaz dęba wymienia m.in. utwór ks. Ludwika Miske Światło Nowego Świata, i Koscioła Chrystusowego, znamienitemi wsławione cudami. Jest tam, poprzedzający kazanie o Franciszku Ksawerym, łaciński wiersz, którego każdy wers, a jest ich dwieście, kryje rok wydania książecz-

39 Rychłowski, Kazania, 308. Pisownia oryginalna.

40 Na temat przekładu leksemu na język polski w XVIII wieku zob. Malińska, „Rzecz o 'mirrowym snopku”, 187-204.

41 Znamy chronostych Mikołaja Reja (Źwierciadło albo kształt, 11), w którym zawarty jest rok jego urodzin, niestety z pomyłką. Z liczenia wychodzi 1405, nie 1505 - rok narodzin pisarza.

42 Hilton, Chronograms Collected, 55.

43 Hilton, Chronograms Collected, 394.

44 Hilton, Chronograms Collected, 56.

45 Miazek, Flora Sinensis, passim; Trelińska, „Intelektualne zabawy w epigrafice”, 175-180; Wich, „Tajemnice warsztatu twórców", 23. 
ki. Strona tytułowa także została opatrzona chronogramiczną datacją: Anno saLUtIs, seU ILLUMInatI a Deo saLVatore orbIs. Łaciński chronogram o znaczeniu „roku zbawienia albo oświeconego świata przez Boga Zbawcę” „niesie” datę $1725^{46}$. Spośród bardzo licznych chronogramów pomieszczonych na stronach tytułowych polskich starodruków wybrano na użytek niniejszego opracowania kilka, które wydają się reprezentatywne dla tego kulturowego fenomenu.

Anno ab ortV soLIs IVstItIae DeI, In VIrgIne Matre LVCentIs [Roku od wschodu słońca sprawiedliwości Boga, jaśniejącego w Matce Dziewicy] (Pruski, 1729). W omówieniu zaznaczono cezurę czasu liczoną od narodzenia Chrystusa (ab ortu...). Inspiracją dla twórcy tej peryfrazy był fragment Księgi Malachiasza: „Et orietur vobis timentibus nomen meum sol justitiae, et sanitas in pennis ejus: et egrediemini, et salietis sicut vituli de armento” $(4,2)$. „Słońce sprawiedliwości”, którego promienie, jak pióra czy skrzydła osłaniają świat, odpowiada w liturgii Chrystusowi opiekującemu się światem ${ }^{47}$. Zauważamy oś symetrii przebiegającą w peryfrazie pomiędzy Starym a Nowym Testamentem: „Słońce sprawiedliwości” jaśnieje w łonie Matki Dziewicy. Suma liter-liczb wskazuje rok 1729.

W omownym wyrażeniu - kryjącym rok 1729 - annô quô MagnVs De CaeLo VenIt heros a VXILI arI humanae vitae maximus ille Deus [W roku, w którym przybył z nieba wielki bohater, największy Bóg, by przyjść z pomocą życiu ludzkiemu] (Awedyk, 1729), interesujące jest użycie słowa „heros”. W ten sposób opisana została data wydania panegiryku upamiętniającego kanonizację Jana Nepomucena. W tytule święty został nazwany Epaminondasem walczącym w obronie szczęścia swojej ojczyzny. Zarówno „heros”, jak i „Epaminondas”, są tymi słowami, które przywodzą na myśl starożytność grecką wraz z jej mitologią, gdzie herosi obdarzeni boskimi cechami, działają w interesie ludzi. W ujęciu etnologicznym podkreśla się relację herosa z Istotą Najwyższą ${ }^{48}$. Nazwanie Chrystusa herosem, jako budzące skojarzenia z pogaństwem, nie mogło pojawić się przypadkowo. Było najpewniej refleksem toczących się dyskusji. Wiadomo, że Maciej Kazimierz Sarbiewski w sposób przekonujący potrafił w XVII wieku pogodzić bajeczną teologię i antyczną filozofię z chrześcijańską doktryną. Dowodem są zarówno traktaty teoretycznoliterackie sarmackiego Horacego, jak i dzieło Dii Gentium. Chrystus został nazwany mianem Herosa w wydanej w 1690 roku teologicznej rozprawie luteranina Christiana Schultza Quaestio an Christus dici possit heros ex hypothesi Platonicorum [...]. Autor, po wnikliwej analizie porównawczej fragmentów Biblii, rozważań platoników i rozmyślań patrystycznych, dochodzi do konkluzji: „huic incomparabili Heroi sit laus, honor et gloria”49.

\footnotetext{
$46 \mathrm{~W}$ chronogramach majuskuła $\mathrm{U}$ traktowana jest jak $\mathrm{V}$ i oznacza cyfrę pięć.

47 Por. przypis do odnośnego fragmentu w Biblii Tysiąclecia (Ml 3,20) oraz Dogondke, „Interpretacja”, 33-47.

48 Zob. Bronk, „Bohater kulturowy”, 730.

49 Schultz, Quaestio an Christus dici possit heros, 10v.
} 
Teologiczny traktat dogmatyczny o Wcieleniu opatrzony jest chronogramem: anno qVo VerbVM In Vera Carne ILLVXIt eXIstentIbVs nobIs In tenebrIs Die 7 ma octobris... [w roku, w którym Słowo zajaśniało w prawdziwym ciele, gdy my żyliśmy w ciemnościach, 7 października] (Stęplowski, 1759) nawiązuje do Ewangelii według św. Jana, której Prolog mówi o Wcielonym Słowie. Liczne fragmenty tego świadectwa W warstwie literackiej wykorzystują antytezę światła i ciemności, np.: „Ego lux in mundum veni, ut omnis qui credit in me, in tenebris non maneat" (J 12,46). Słowa o prawdziwym ciele mogą nasunąć skojarzenia $\mathrm{z}$ fragmentem mowy eucharystycznej (J 6,48-59).

Treść chronogramicznej peryfrazy annô quô Mors DefraCta SaCrô LIgnô Vitae IngerIt orsa [roku, którego śmierć złamana świętym drzewem wprowadza początek życia] (Stobiecki, 1759) jest oczywista, pomimo nasycenia metaforyką. Drzewo ma bardzo bogatą symbolikę. W Biblii pojawia się w Księdze Rodzaju jako stojące pośrodku Edenu drzewo życia i drzewo poznania dobra i zła (Rdz 2,9). Frekwencja występowania wyrazu drzewo w Biblii (w Wulgacie - lignum, arbor) jest bardzo duża i przeważnie leksem ma symboliczne znaczenie. Klamrę otwiera drzewo z Księgi Rodzaju, a zamyka symbolizujące przywrócenie łaski drzewo z Apokalipsy $(22,2)$ : „Pomiędzy rynkiem Miasta a rzeką, po obu brzegach drzewo życia, rodzące dwanaście owoców - wydające swój owoc każdego miesiąca - a liście drzewa [służą] do leczenia narodów". W prezentowanej peryfrazie drzewo symbolizuje krzyż.

Krzyż Chrystusa zwrócił nam raj - głosi św. Ambroży - Oto drzewo, które Pan wskazał Adamowi, by z niego spożywał, mówiąc o drzewie życia, które rosło pośrodku raju.[...] Dlatego Pan w Chrystusie połączył ciało i drzewo, aby ustał odwieczny głód i przywrócona została łaska życia. O błogosławione drzewo Pana, na którym ukrzyżowane zostały grzechy wszystkich ${ }^{50}$.

O przywróceniu rajskiego ogrodu mówi inny chronogram, skrywający rok 1765 : anno quo arbores et herbas horto fragrantes fLos MIro ChrIstVs reCreaVIt oDore nItorIs [w roku, w którym drzewa i zioła kwitnące w ogrodzie kwiat - Chrystus ożywił niezwykłym zapachem piękna] (Szopiarski, 1765). Najpewniej i tu chodzi o ofiarę krzyża. Wskazuje na to słowo „recreavit” - stworzył na powrót, ożywił.

Nie ulega wątpliwości, że motyw ukrzyżowania kryje się w kolejnej peryfrazie. Chronogram z rokiem 1712 - anno, quo Mors et VIta ratae fortI Certare DVeLLo [w roku, w którym śmierć i życie postanowiły zetrzeć się w ważnej bitwie] (Sanecki, 1712) - czerpie z obecnej wciąż w liturgii, powstałej w średniowieczu sekwencji wielkanocnej Victimae Paschali Laudes. Jedna z jej strof zawiera słowa: „Mors et vita duello/ conflixere mirando:/ dux vitae mortuus, regnat vivus”. „Śmierć starła

50 Ambrosius Aurelius, Enarrationes in XII psalmos Davidicos (PL 14, 999). Podaję za: Forstner, Świat symboliki chrześcijańskiej, 154. 
się z życiem..." - śpiewamy tę pieśń w staropolskim przekładzie. Po raz kolejny widzimy, jak rozumiany jest w tych omówieniach „Anno Domini” czas. W chronogramach konkretna data roczna, zakamuflowana w słowach, schodzi na plan dalszy. Na pierwszym planie jest treść teologicznego przekazu, który nie wskazuje na Boże Narodzenie, od którego liczy się „nasza era”, ale także na inne wydarzenia w ekonomii zbawienia.

Przeważająca część omownych wyrażeń na stronach tytułowych starych druków indeksowanych w Bibliografii Staropolskiej Karola Estreichera zapisana została po łacinie. Przekład stanowi interpretację, jest subiektywny. Dlatego szczególnie cenne są sporadycznie występujące chronogramy spisane po polsku. Autorzy stworzyli w nich specyficzną grafię: literę „W” tworzy podwójne „W”. Dzięki temu uzyskali wartość liczbową. Chronogramiczne „VV” odpowiada dziesiątce. W chronogramie W roku DrogI I praVVDy przeDVVIeCzney, XIegI ŻyVVota otVVartey, ChrystVsa (Dowód, $1760)$ odczytujemy aluzję do dialogu Jezusa $z$ uczniami z Janowej ewangelii $(14,6)$ „Jezus odpowiedział: Ja jestem drogą, prawdą i życiem. Nikt nie przychodzi do Ojca inaczej, jak tylko przeze Mnie". Otwarta księga żywota nawiązuje do sądu narodów w Janowym Objawieniu. Celem życia każdego człowieka winno być pragnienie, by jego imię zostało zapisane w księdze życia. Może się to dokonać poprzez podążanie drogą wiary i naśladowanie Chrystusa. W innym razie człowieka czeka potępienie: "Jeśli się ktoś nie znalazł zapisany w księdze życia, został wrzucony do jeziora ognia” (Ap 20,15). Zawierająca tę peryfrazę strona tytułowa zapowiada dramatyczny utwór o Ulissesie. Być może znajdujący się w opisie roku wydania wyraz „droga” miał nawiązywać do archetypicznej wędrówki bohatera Odysei.

Za kodę części niniejszego studium, prezentującej przykłady wyrażeń omownych, niech posłuży wyrażony po polsku chronogram informujący na stronie tytułowej panegiryku o roku zawarcia związku małżeńskiego. Wierszowana fraza o dogmatycznej wymowie - Na zIeMI DzIeło nasze czynIł Bóg VVCIeLony, Dlatego Zbawicielem świata ogłoszony (Matawowski, 1765) - kryje rok 1765.

W Bibliografii Staropolskiej Karola Estreichera możemy znaleźć jeszcze bardzo liczne peryfrazy „anno Domini”, których tak forma, jak i treść mogą budzić zdumienie dzisiejszego czytelnika. Część indeksowanych przez bibliografa książek już nie istnieje z powodu zawirowań historii. Okazuje się jednak, że dzięki dokładnym opisom konstrukcyjnych elementów strony tytułowej książek dawnych, przygotowywanych do edycji z wielką pieczołowitością zarówno pod względem treści, jak i formy - słowa i grafii, możemy w pewnym stopniu dotknąć tamtego czasu. Jak pisze współczesny badacz literatury:

właśnie owo połączenie elementów kultury słowa i kultury pisma (druku) świadczy o badawczym potencjale literatury dawnej, szczególnie zaś tych staropolskich tekstów, któ- 
rych - wydawałoby się - ze względu na ich tradycyjnie ustalone miejsce w hierarchii zjawisk historycznoliterackich, nie sposób już inaczej interpretowaćs ${ }^{51}$.

Powszechna dostępność cyfrowych wersji książek pozwala docenić także wysiłki bibliopolów w wymiarze estetycznym. Zaprezentowane w niniejszym opracowaniu peryfrazy „roku Pana” utrzymują się w ramach konwencji, przez co utrwalają pewien określony styl widzenia i styl czytania świata ${ }^{52}$. Autorzy omówień żądają od czytelnika tych sprawności, których sami dowiedli: znajomości Biblii, dogmatyki, elementów liturgii, dzieł patrystycznych, zdolności wnioskowania, biegłości w zakresie poetyki i retoryki, wyczucia literackiego, zdolności do intelektualnego wysiłku przy rozwiązywaniu chronogramów. Dla dzisiejszego odbiorcy są to z pewnością wymagania wygórowane, ale też z tego powodu temat wart jest - w mojej opinii - zgłębienia.

Można zatem potraktować ten szkic jako prolegomena, ponieważ, o czym była już mowa, materiał nie został do tej pory objęty refleksją naukową, a wydaje się, że może stanowić przedmiot badań teologów, literaturoznawców, teoretyków komunikacji, neolatynistów.

Przynajmniej jeden bezsprzeczny wniosek można wysnuć z przeprowadzonej na użytek tego opracowania lektury: inwencja autorów peryfrastycznych wyrażeń „anno Domini” zdaje się mieć granice wyznaczane jedynie prawomyślną religijnością. Stopień skomplikowania, enigmatyczność, stylistyka omówień każą widzieć w edytorach sprawnych językowo erudytów o wrażliwości estetycznej odzwierciedlającej literacki smak epoki.

\section{Bibliografia}

Ambrosius Aurelius, Enarrationes in XII psalmos Davidicos (PL 14).

Antonius Patavinus, In Festo S. Ioannis Evangelistae, http://www.documentacatholicaomnia.eu /03d/1195-1231,_Antonius_Patavinus,_Sermo_061_in_Festo_S_Ioannis_Evangelistae,_ LT.pdf [dostęp: 15.04.2020] 5-6.

Bańko, M., „Peryfrazy w naszym życiu”, Poradnik Językowy 9 (2002) 3-23.

Bańko, M., Słownik peryfraz, czyli wyrażeń omownych (Warszawa: PWN 2003).

Biblia Tysiąclecia (Poznań: Pallotionum 2003).

Biblia Sacra juxta Vulgatam Clementinam, edycja cyfrowa (red. M. Tweedale) (London [s.n.] 2005) http://vulsearch.sourceforge.net/vulgata-2col.pdf [dostęp: 28.10.2020].

Bilska-Wodecka, E. et al., „Kult św. Antoniego w Polsce na przykładzie wezwań parafii i ośrodków sanktuaryjnych", Peregrinus Cracoviensis 16 (2005) 279-286.

Blume, C. - Dreves, G.M. (ed.), Analecta Hymnica medii aevi (Leipzig: Reisland 1898-1903) I-L.

51 Głażewski, „Lekcja retoryki doktora Markolfa”, 94-95.

52 Lichański, „Metafora”, 225. 
Bronk, A., „Bohater kulturowy”, Encyklopedia katolicka (Lublin: Towarzystwo Naukowe KUL 1976) II, 731-732.

Cornelius a Lapide, „Commentaria in librum sapientiae”, Commentarii in sacram scripturam (Paris: Vivès 1846) IV, 587-848.

Dogondke, D., „Interpretacja mesjańska wyrażenia „słońce sprawiedliwości” (Ml 3,20)”, Verbum Vitae 26 (2014) 33-47.

Drączkowski, F., „Dionizy Mały”, Encyklopedia katolicka (Lublin: Towarzystwo Naukowe KUL 1979) III, 1340-1341.

Estreicher, K., Bibliografia polska (Kraków: W Drukarni Uniwersytetu Jagiellońskiego 1872-1908) I-XXII.

Forstner, D., Świat symboliki chrześcijańskiej (Warszawa: Instytut Wydawniczy Pax 1990).

Głażewski, J., „Lekcja retoryki doktora Markolfa. Uwagi na temat oralności i piśmienności w kulturze staropolskiej (na przykładzie dzieła Jana z Koszyczek)", Odrodzenie i Reformacja w Polsce 55 (2011) 91-99.

Głowiński, M., „Peryfrazy współczesne”, Teksty 3 (1972) 48-58.

Hanusz, J., O książce do nabożeństwa króla Zygmunta I w rękopisie monachijskim (Kraków: Drukarnia Uniwersytetu Jagiellońskiego 1884).

Hilton, J., Chronograms Collected. More Than 4000 in Number, Since the Publication of the two Preceding Volumes in 1882 and 1885 (London: Stock 1895).

Hipper, J.J., Maria Virgo Sacratissima Mater Pulchrae Dilectionis Immaculate Concepta In recurrente Anniversario Ejus Conceptionis Festivo die, Anno 1730. Pragae in Ecclesia RR.PP. Minorum Ord. S. Francisci Seraphici Strictioris Observantiae Hybernorum Panegyrico Sermone proposita ([s.l.]: Caroli Joannis Hraba, Inclyt. Regni Bohemiae Statuum Typogr. 1730).

Jacniacka, M., „Hortus conclusus”, Encyklopedia katolicka (Lublin: Towarzystwo Naukowe KUL 1983) VI, 1238.

Klawek, A., „Biblijne symbole maryjne”, Ruch Biblijny i Liturgiczny 9/4-6 (1956) 216-227.

Kowalczyk, S., „Anamneza”, Encyklopedia katolicka (Lublin: Towarzystwo Naukowe KUL 1973) I, 510-511.

Kowalewska, M., „System Elektronicznej Bazy Bibliografii Estreichera (EBBE). Tradycja strzeżona w rekordach", Nihil sine Litteris. Scripta in honorem Professoris Venceslai Walecki (red. T. Nastulczyk - S. Siess-Krzyszkowski) (Kraków: Wydawnictwo UJ 2017) 385-395.

Lichański, J., „Metafora. Analiza zjawiska na przykładzie polskiej poezji wczesnobarokowej”, Prace Polonistyczne 39 (1983) 205-228.

Machnicka, V., „Konstrukcje peryfrastyczne związane ze śmiercią na tle innych określeń omownych w Faraonie Bolesława Prusa”, Styl [Belgrad] 4 (2005) 343-355.

Majdak, M., Głos. Studium leksykograficzne (Kraków: Instytut Języka Polskiego PAN 2019).

Malińska, A., „Rzecz o 'mirrowym snopku'. W poszukiwaniu znaczenia i popularności użycia w XVIII wieku", Bogactwo polszczyzny w świetle jej historii (red. J. Przyklenk) (Katowice: Wydawnictwo UŚ 2014) V, 187-204.

Martinus Legionensis, Sermo XXXII (PL 208, 1203-1266).

Mehlmann, J., Natura filii irae. Historia interpretationis Eph. 2, 3 eiusque cum doctrina Peccato Originalis nexus (Analecta Biblica 6; Roma: Pontoficio Instituto Biblico 1957).

Miazek, M. Flora Sinensis Michała Boyma SI (Gniezno: Wydawnictwo Fundacji Collegium Europaeum Gnesnens 2005). 
Nadolski, B., Liturgika. II. Liturgia i czas (Poznań: Pallottinum 1991).

Nastulczyk, T., „Elektroniczna Baza Bibliografii Estreichera (EBBE). Nowe funkcjonalności i perspektywy badawcze", Bibliotheca Nostra 48 (2017) 122-129.

Petrus Lombardus, Collectaneorum in Epistolas Paulum continuatio (PL 192, 9-520).

Piotr Chryzolog, „Homilia na Zwiastowanie Najświętszej Panny (1-4)”, Piotr Chryzolog, Teksty o Matce Bożej. II. Ojcowie Kościoła łacińscy (tł. W. Eborowicz - W. Kania; wstęp W. Kania) (Niepokalanów: Wydawnictwo Ojców Franciszkanów 1981) 129-142.

Rej, M., Źwierciadło albo kształt, w którym każdy stan snadnie się może swym sprawam, jako we źwierciadle, przypatrzyć (wyd. J. Czubek - J. Łoś; wstęp I. Chrzanowski) (Kraków: Akademia Umiejętności 1914) I.

Rychłowski, F., Kazania na niedziele całego roku (Kraków: W Drukarni Stanisława Piotrowczyka 1664).

Schultz, Ch., Quaestio an Christus dici possit heros ex hypothesi Platonicorum? [...], (Leipzig: Goetz 1690).

Sedulius Caelius, „Paschale carmen”, Sedulius Caelius, Opera omnia (tł. i red. H. Wójtowicz) (Lublin: Towarzystwo Naukowe KUL 1999) 86-221.

Sobór Watykańskie II, „Konstytucja dogmatyczna o objawieniu Bożym Dei verbum”, Sobór Watykański II. Konstytucje, dekrety, deklaracje. Tekst polski (Poznań: Pallottinum 2002) 350-363.

Szlaga, J., „Anno Domini”, Encyklopedia katolicka (Lublin: Towarzystwo Naukowe KUL 1973) I, 631-632.

Trelińska, B., „Intelektualne zabawy w epigrafice”, Rocznik Łódzki 61 (2014) 175-180.

Vivien, M., Tertullianus Praedicans [...] (Augsburg: Schlüter \& Happach 1715) I.

Wąsowicz, H., „Era chrześcijańska”, Encyklopedia katolicka (Lublin: Towarzystwo Naukowe KUL 1983) IV, 1050.

Weintraub, W., „Ostatni tom Bibliografii Estreichera”, Nauka i Sztuka 1/2-3 (1945) 236-248.

Wich, U., „Tajemnice warsztatu twórców polskiej poezji mnemotechnicznej (od XIV do XVIIII wieku) na przykładzie akrostychu i chronostychu", Acta Universitatis Lodzensis. Folia Litteraria Polonica 13 (2010) 19-33. 
